семьи, а уже затем проводят проверку, результаты которой нередко выглядят необъективными.

В таком случае, это уже не политика защиты детей - это уже бизнес.

И если мир делится на черное и белое, а бизнес на чистый и грязный - можно поспорить на что угодно: «ювенальный бизнес» быть чистым не может.

Когда на одной чаше весов ребенок, а на другой деньги - родная семья оказывается «третьей лишней».

Что может быть страшней в стране, которую мы все еще называем демократической?

$$
* * *
$$

1. Конвенция о правах ребенка (одобрена Генеральной Ассамблеей ООН 20.11.1989) (вступила в силу для СССР 15.09.1990).

2. Конституция Российской Федерации (принята всенародным голосованием 12.12.1993) (с учетом поправок, внесенных Законами РФ о поправках к Конституции РФ от 30.12.2008 N 6-ФКЗ, от 30.12.2008 N 7-ФКЗ, от 05.02.2014 N 2-ФКЗ, от 21.07.2014 N 11-ФКЗ).

3. Кодекс Российской Федерации об административных правонарушениях от 30.12.2001 N 195-Ф3 (ред. от 18.03.2019) (с изм. и доп., вступ. в силу с 29.03.2019).

4. Семейный кодекс Российской Федерации от 29.12.1995 N 223-Ф3 (ред. от 18.03.2019).

5. Уголовный кодекс Российской Федерации от 13.06.1996 N 63-ФЗ (ред. от 27.12.2018) (с изм. и доп., вступ. в силу с 08.01.2019).

6. Уголовно-процессуальный кодекс Российской Федерации от 18.12.2001 N 174-Ф3 (ред. от 06.03.2019).

7. Федеральный закон от 24.06.1999 N 120-Ф3 (ред. от 27.06.2018) «Об основах системы профилактики безнадзорности и правонарушений несовершеннолетних».

8. Федеральный закон от 24.04.2008 N 48-Ф3 (ред. от 03.08.2018) «Об опеке и попечительстве».

9. Федеральный закон от 21.11.2011 N 323-Ф3 (ред. от 06.03.2019) «Об основах охраны здоровья граждан в Российской Федерации».

10. Постановление Пленума Верховного Суда РФ от 27.05.1998 N 10 (ред. от 26.12.2017) «О применении судами законодательства при разрешении споров, связанных с воспитанием детей».

\title{
Kostenko D.S. \\ Comparative analysis of genesis and evolution of jury trial in Russia and England
} Law School of Siberian Federal University (Russia, Krasnoyarsk)

doi: 10.18411/scienceconf-05-2019-42

idsp: scienceconf-05-2019-42

\section{Abstract}

The foundation of the institution of trial by jury was not laid in any act of the legislature, but it arose silently and gradually out of the usages of a state and society. There are various and conflicting opinions expressed by historians and writers as to the origin of this institution. Jury procedure permitted much of the work in judication deciding contest cases to ordinary citizens persons untrained in the law. In England the challenges of operating a jury based procedures system have exercised a shaping influence on match of the legal system. Across the centuries jury trial underwent incessant change and was adopted in different legal systems across the world, particularly in Russia.

Key words: history, jury trial, judicial system, jury board, justice.

The jury system was develop In XII-XIII centuries of history of England. It refers to the period, when the Crown took the steps that committed the common law to jury based procedure. Juries in this period were called self-informing. Jurors were drawn from the closest vicinity of the events in dispute in the expectation that at least some of them would already know something about the facts or at least be well positioned to find out. They are also described as "a man chosen as being likely to be already informed" [1]. They were expected to form their verdict and more often come to court to speak, then to listen.

Most people lived in largely self-sufficient villages that were engage in a particular substance of agriculture. Working on the open field system, the villagers pulled their labor, they 
worked collectively on each other's land, presumed to a communally administrative program of plowing, planting, harvesting. The policing function in these communities was also communal, because the able body males of the village were organized in the policing groups for responding to attacks on personal property. This form of social organization led to a very high levels of social interaction.

The power implication of early jury system is impressive. On the one hand being a juror was not a welcome experience - the crown had coursed you to take on an unpleasant morally troublesome work of setting the judgment on the life and affairs of your neighbors. On the other hand jury procedure entailed a significant component of power sharing, because the system placed the power of the judication in the hands of these citizens groups.

The roots of the failure of the government in organizing the effective system of evidence gathering is to be found in the early conception of jurors as bearers of the knowledge needed to resolve disputes. By assuming that the jurors had already knew the facts, the jury system defaulted on the central task of the system. Moreover, jury system was not organized to probe witness testimony which is in modern understanding a sort of evidence that is essential for rational judication.

The self-informant jury system was declined in XIV-XV centuries, so the different conception of jury trial came to prevail. Jury trial system changed function and became primarily in occasion of educating the jurors about the facts. This phase may be called as instructional trial.

In a much elaborating form, this conception of a jury trial endeavors to modern day. The emergence of instructional trial supposes that the work of gathering and presenting evidence would be assumed by the persons other than the jurors.

The Black Death, which struck in 1349 , led to the huge population losses. This lead to new tendency of labor mobility that left old style agrarian villages no longer viable. Because of this, jurors start to be drawn from the county wide pool who's members were far less likely able to collect knowledge's about the dispute.

In criminal cases the shift to jury ignorant of the facts, posed a significant investigative challenge. In the era before professional police forces or prosecutorial corpse who would gather and present criminal evidence to the jurors, the initial response was to place heavy reliance on the victim who also called victim-prosecutor. By the middle of the XVI century the Crown took the steps to have a public officer assist the victim in pre-trial and trial procedure. But the investigation regime came with the investigation defect on its own - a one sidedness that would generate accusing evidence only.

To the XVIII century the shift from the self-informing jury to the instructional trial affected the change of power balance, what have been near the monopoly of knowledge about the facts of the case. The judge found himself learning the evidence of the case at least as well as the jurors. That development enabled the judge to exercise greater influence over the jury. The functional reality was that the judicial comment allowed the judge to influence the jury's verdict.

By the XIX century "Jurors in general follow the advice of the judge and therefore the substance of the verdict is found by the judges direction. Closely connected to judicial comment on the evidence was the extensive power that the judge is developed to instruct jurors or what the judge chose to characterize as issues of law. Instructions of this sort commonly dealt with what inferences jurors should draw from particular fact pattern. This technique of recasting fact issues as questions of law, subject to judicial instruction, resulted in a stain narrowing in the jurors sphere of responsibility for fact finding process.

Rule of hearsay or the confession rule provided trial judges with still further power to decide what sorts of evidence the jurors would be allowed to study. The jurors were expected by the trial judge to disclose the thinking lead them to the verdict that supposed to render. Having learned the basis for the verdict the trial judge could refuse to accept it, instruct the jurors further and send them back to deliberate it again.

Jurors power was nominally respected by granting the party who loss the trial with the right to have the case retried to another jury. In this way a new trial downplayed the question of the initial verdict. If the judge who tried the cause declare himself satisfied with the verdict it have been usual not have grand a new trial. On the other hand if the judge declares dissatisfied with the verdict it is pretty much the cause of a new trial. Another words, jury control weakened the jury authority [2]. 
The development of civil justice seriously affected on the trial proceedings in a whole. In XIX century jury trial was inseparable, there was no such thing as non-jury trial in a common law civil case.

The transformative development in criminal justice of XIX-XX centuries has been an emergence of professional policing and prosecution emergence of vast expansion. This development finally succeeded in overcoming the investigation deficit that has humbled jury based criminal justice across the prior centuries. The prosecutor that was expected to propel the criminal trial in former times has today become simply a witness in a state run prosecution based on police generated evidence. Professional policing and prosecution brought improvements in quality and quantity of criminal evidence. Professionalization of the work of criminal investigation led to professionalization of charging function that is formulating the official criminal charge.

The ancient grand jury historic route of the jury tradition became obsoleted and was abolished by legislation in 1933. Since the late XVIII century legislation expanded range of summary offences, the early XIX century movement to ameliorate this criminal law resulted in extensive statutory classification and downgrading capital crimes trialed by jury (such as arson), which became triable by the magistrates. Thereafter, new offences, in economics for example, have increased the role of summary jurisdiction.

Criminal jury trial has changed character in many ways since the days of self-informing jury, but one great constant is that now as then jury trial defuses the judicative power away from officialdom. There always be cases in which from the nature of events or the persons involved officialdom seems compromised appear compromised and that is why criminal jury trial although greatly diminished continues to survive at least for now.

The concept of the system of jury trial was spread among the world, so the legal systems of different countries adopted it in accordance to the specific national features. It is crucial to mention, that the fundamental elements of the jury trial were established in the Russian legislation long before the complete system of Russian jury trial was adopted. Thereby, the legal code of Kievan Rus' (Russkaya Pravda) mentioned that a person accused of larceny, but who have been denying his/her guilt, should appear before 12 man, who are able to decide the question of guilt.

To the end of XVIII century the idea of adaptation of jury trial in Russia become very topical, especially in contrast to the progressive judicial standards of Western Europe.

With the judicial reform of 1864 jury trial was completely set as an independent legal institute in Russia. The main goal of the reform was to provide trust in decision of the judge, so that trust will provide stability of the state and steadiness of the court's decision [3].

Russian jury trial has unique and comprehensive way of its evolution, which is significantly differs from the foreign countries and England in particular. This contradiction mainly caused by the turning points of Russian political history, consequently, there are more formation periods to describe.

After the above mentioned period of great reforms of 1864, in which jury system was created, the reverse process of counter reforms was initiated. It started in 1870 and was concluded in decreasing the amount of rights of the jurors and their jurisdiction in criminal procedure.

However, despite of this by the beginning of the XIX century the jury system was stabilized and decisively adopted as a part of the justice mechanism. Jury trial even passed the verdicts in the period of World War I, although the military situation often limits the activities of democratic institutions [4].

The period of 1917-1950 marked by the adoption of the decree "On Court" which banned the institution of jury trial. The absence of jury was until the $1980 \mathrm{~m}$ when the Soviet Government adopted the law "On approval of the Fundamentals of Legislation on the Judicial System of the USSR and Autonomous Republics". This law set the rule of consideration of all cases in the court of first instance with the representatives of general public alongside with the professional judge.

In modern Russia, the right of citizens "in the administration of justice" is enshrined in part 5 of article 32 of the Constitution of the Russian Federation. Jury trials are carried out on the basis of the Criminal Procedure Code and the federal law "On jury assessors of federal courts of general jurisdiction in the Russian Federation" dated August 20, 2004. Criminal cases involving jurors are considered in the Supreme Court of the Russian Federation, the supreme courts of the 
republics, regional, regional, district courts, courts of cities of federal significance, and district (naval) military courts. Moreover, from June 1, 2018, the jury institute is introduced in district courts and garrison military courts.

Despite the differences political history and differences in judicial system there are common parts in the process of the formation of jury trial in Russia and England. Although Russian jury trial was adopted much later than in England, the essence of administration the justice by people unqualified in law had a positive impact on the judicial system and society. Both countries faced a problem of reducing the jury competence, at the same time paying tribute to the division of powers of the judiciary and the development of democratic institutions.

$* * *$

1. James Bradley, A preliminary treatise on evidence at the common law pp. 47-84. 1898.

2. John Langbein (2015) The four epochs of jury trial in England [audio lecture] // https://soundcloud.com/britishacademy/the-four-epochs-of-jury-trial-in-england/s-VAI6Z.

3. Зарудин, С.И. Общие соображения о составе суда: Материалы. Т. 17. СПб., 1879.

4. Ифланд П.А. Присяжные заседатели и война // ЖМЮ. 1917. №5. С.214. 